\title{
Callus Derived Regeneration of Some Selected Brassica Genotypes
}

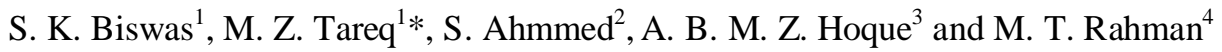 \\ ${ }^{1}$ Jute Agricultural Experimental Station, Bangladesh Jute Research Institute (BJRI), Manikganj, \\ Bangladesh; ${ }^{2}$ Pest Management Division and ${ }^{3}$ Genetic Resource \& Seed Division, BJRI, Dhaka, \\ Bangladesh; ${ }^{4}$ Jute Seed Production and Research Division, BJRI, Dinajpur, Bangladesh \\ *Corresponding author and Email: zablulbarj@gmail.com
}

Received: 25 January 2017

Accepted: 22 December 2017

\begin{abstract}
The experiment was conducted to observe the callus induction ability of Brassica species. Plantlets were regenerated from cotyledon and stem explants of Brassica napus, Brassica campestris and Brassica juncea through direct organogenesis. The experiments were conducted in a Completely Randomized Design (CRD) with 4 replications. The highest frequency of callus formation was recorded in MS containing $2.0 \mathrm{mgl}^{-1} \mathrm{BAP}, 0.5 \mathrm{mgl}^{-1} \mathrm{NAA}$ and $2.0 \mathrm{mgl}^{-1} \mathrm{AgNO}_{3}$ in both stem and cotyledon explants. Among these explants, stem was found to be better responsive in callus induction than cotyledon. Among the genotypes used, BINA Sarisha-4 induced the highest percentage (100.00\%) of callus from stem explants which was followed by BINA Sarisha-5 (100.00\%) and Sampad $(83.35 \%)$. On the other hand, BINA Sarisha-4 induced callus from $91.67 \%$ cotyledon explants, followed by BINA Sarisha-5 (75.00\%) and Sampad (66.67\%). Similarly, the highest percentage of shoot regeneration (58.34\%) from stem explants of BINA Sarisha-4 was observed in MS medium supplemented with combination of hormone and silver nitrate concentrations. The highest percentage of root induction was 66.67 and $58.33 \%$ in plantlets derived from stem and cotyledon explants, respectively in $1 / 2 \mathrm{MS}$ medium supplemented with $2.0 \mathrm{mgl}^{-1} \mathrm{IBA}$ and $0.5 \mathrm{mgl}^{-1}$ of NAA. The highest survival rate was found after acclimatization of plants derived from stem $(77.78 \%)$ and cotyledon (64.28\%) explants of BINA Sarisha-4 in pot and 64.33 and $55.55 \%$, respectively in field.
\end{abstract}

Keywords: In vitro, Organogenesis, Cotyledon and Stem explants, Mustard.

\section{Introduction}

Mustard (Brassica spp.) is one of the most important oil crop of the world belongs to the family Brassicaceae (formerly Cruciferae). It is a popular edible oil crop in rural area of Bangladesh and is considered important for improving the taste of a number of food items. It also serves as an important raw material for industrial uses such as in soap, paints, varnishes, hair oils, lubricants, textile auxiliaries, pharmaceuticals, etc (Alam et al., 2015). About $13.2 \%$ of the annual world edible oil supply comes from this crop (FAO, 2007). The seeds of mustard and rapeseed contain $42 \%$ oil and $25 \%$ protein (Khaleque, 1985). Brassica (rapeseed and mustard) is the top most oil producing crop in this country. It is the third most important edible oil source in the world after soybean and palm (Piazza and Foslia, 2001; Walker and Booth, 2001).

Brassica spp. has consistently proven to be one of the most recalcitrant members of the Brassiceae in tissue culture (Hachy et al., 1991). Due to high degree of segregation upon crops pollination and unavailability of suitable wild 
germplasm of Brassica spp., in vitro breeding is the situation demand in this moment for variety development. On the other hand, conventional breeding is time consuming and labor intensive for performing crossing and selection of desirable genetic trait(s). Moreover, genetic incompatibilities restrict much potentially important gene transformation by interspecies hybridization. An efficient tissue culture system is thought to be crucial to the success of plant genetic engineering. This technique can be used to add desirable trait from wild to existing cultivars within a shorter period. The main advantage of tissue culture technology lies in the production of high quality and uniform plant material that can be multiplied in a year round basis under disease free conditions. Therefore, in vitro techniques are considered to be alternative tools of conventional breeding method for the improvement of Brassica spp. (Biswas, 2008). So far in vitro techniques for regeneration of Brassica are not exactly established in Bangladesh. Therefore, there is a need of study on the regeneration technique to improve the in vitro breeding of Brassica. To fill up the need the present study was undertaken to study the in vitro regeneration potentiality of four selected Brassica genotypes.

\section{Materials and Methods}

\subsection{Plant materials}

Four different varieties of Brassica spp. such as BINA Sarisha-4 and BINA Sarisha-5 of Brassica napus, 'Sampad' of Brassica campestris and 'Shambal' of Brassica juncea were used in this study. The seed materials were collected both from Bangladesh Institute of Nuclear Agriculture (BINA) and Bangladesh Agricultural University (BAU), Mymensingh. Present research activities were conducted at the Tissue Culture Laboratory of the Department of Genetics and Plant Breeding, BAU, during the year 2007-2008.

\subsection{Culture medium and explants used}

Mature seeds of Brassica napus, Brassica juncea and Brassica campestris were surface sterilized in a sequential manner with $70 \%$ ethyl alcohol for five minutes, $0.1 \% \mathrm{HgCl}_{2}$ with 1-2 drop Tween-20 for five minutes followed by treatment with sodium hypochlorite (2.5\% Chlorine) for five minutes and subsequently rinsed four to five times with sterile distilled water. Sterilized seeds were germinated aseptically on half-strength MS basal medium. MS medium contained inorganic salts of MS medium, vitamins, $20 \mathrm{gml}^{-1}$ sucrose and 6 gm agarose (Difco-brand Bacto Agar). The $\mathrm{pH}$ of all culture medium used in this study was adjusted to 5.8 before autoclaving at $121^{\circ} \mathrm{C}$ for 30 minutes. Cotyledons with 1-2 mm petiole and stem segments of 2 to $3 \mathrm{~mm}$ in length were cut from four-day old germinated seedlings. Cotyledons were placed upright with cut ends embedded in the culture medium and stem segments were cultured horizontally and pressed down gently into the medium. Four explants were cultured per Petridish. The cultured plates were sealed using micro porous tape and incubated at $22 \pm 2{ }^{\circ} \mathrm{C}$ using 16-hr. day length (2000Lux). Color, nature and abundance of callus were observed visually after three weeks of incubation and graded accordingly. The color graded the marks as 3 for green, 2 for creamy and 1 for yellow color; in case of nature of callus 3 for compact, 2 for friable and 1 for looses in texture and in case of abundance of callus 3 for plenty, 2 for moderate and 1 for poor amount. Callus induction and shoot regeneration from stem segment and cotyledon of four Brassica genotypes were cultured on MS medium supplemented with different concentrations of BAP ( 1 and $2 \mathrm{mgl}^{-1}$ ) and NAA (0.5 and $1.0 \mathrm{mgl}^{-}$ $\left.{ }^{1}\right)$ with constant concentrations of $\mathrm{AgNO}_{3}$ (2.0 $\mathrm{mgl}^{-1}$ ) in order to induce shoot from unorganized calli. After two weeks shoot initiation was visible and well developed shoots (3-4 cm long) were cultured on root induction medium (halfstrength MS) supplemented with different concentrations of IBA $\left(1,2\right.$ and $\left.3 \mathrm{mgl}^{-1}\right)$ with constant concentration of NAA $\left(0.5 \mathrm{mgl}^{-1}\right)$. After 12 weeks culture the number of shoots per explants was recorded. Most of the shoots become rooted on rooting medium. Rooted shoots were planted in a mixer soil containing $25 \%$ garden soil $+50 \%$ sand $+25 \%$ cow dung in 
plastic pots and kept in a lath house for hardening before transferring them to field. The experiments were conducted following Completely Randomized Design (CRD) with 4 replications.

\subsection{Statistical analysis}

The data collected on different characters were analysis statistically to find out the analyses of variance and means were compared by the Duncan's Multiple Range Test (DMRT).

\section{Results and Discussion}

\subsection{Callus induction from stem explants}

Stem explants of all genotypes cultured on MS medium supplemented with different concentration of BAP and NAA induced visible callus by swelling of two cut ends of explants within six days of incubation. Callusing performance of stem segment from genotype BINA Sarisha-4 showed excellent result in all the combinations, of which $\mathrm{MS}+2 \mathrm{mgl}^{-1} \mathrm{BAP}+$
$0.5 \mathrm{mgl}^{-1} \mathrm{NAA}+2 \mathrm{mgl}^{-1} \quad \mathrm{AgNO}_{3}$ showed $100 \%$ callusing and $\mathrm{MS}+2 \mathrm{mgl}^{-1} \mathrm{BAP}+1 \mathrm{mgl}^{-1} \mathrm{NAA}+$ $2 \mathrm{mgl}^{-1} \quad \mathrm{AgNO}_{3}$ showed $91.66 \%$ callusing. Callusing performance was the lowest $(75.00 \%)$ in $\mathrm{MS}+1 \mathrm{mgl}^{-1} \mathrm{BAP}+1 \mathrm{mgl}^{-1} \mathrm{NAA}+2 \mathrm{mgl}^{-1}$ $\mathrm{AgNO}_{3}$ stem segment from the genotype BINA Sarisha-5 also showed the best performance $(100 \%)$ with $\mathrm{MS}+2 \mathrm{mgl}^{-1} \mathrm{BAP}+0.5 \mathrm{mgl}^{-1} \mathrm{NAA}$ $+2 \mathrm{mgl}^{-1} \mathrm{AgNO}_{3}$. And $66.67 \%$ with $\mathrm{MS}+1 \mathrm{mgl}^{-}$ ${ }^{1} \mathrm{BAP}+1 \mathrm{mgl}^{-1} \mathrm{NAA}+2 \mathrm{mgl}^{-1} \mathrm{AgNO}_{3}$. Callus induction was the lowest in Shambal (50.00). It was also observed that the genotype Shambal and the combination $\mathrm{MS}+1 \mathrm{mgl}^{-1} \mathrm{BAP}+1 \mathrm{mgl}^{-1}$ $\mathrm{NAA}+2 \mathrm{mgl}^{-1} \mathrm{AgNO}_{3}$ showed the lowest performance (Table 1). Similar result was found by Saha et al. (1997) who reported that callus induction was greatest with $2 \mathrm{mgl}^{-1} \mathrm{BAP}+0.2$ $\mathrm{mgl}^{-1}$ NAA. Ratan et al., (2000) also reported that callus induction high in MS media with 2 $\mathrm{mgl}^{-1}$ BAP. This investigation exhibited that both the high and low concentration of BAP and NAA influences callusing performance.

Table 1. Interaction effects of hormone $\times$ genotype on callus induction of stem and cotyledon explants of Brassica spp.

\begin{tabular}{clcc}
\hline \multirow{2}{*}{$\begin{array}{c}\text { Supplements in } \mathrm{mgl}^{-1} \\
\text { BAP+NAA+AgNO }\end{array}$} & Genotype name & Stem explant & Cotyledon \\
\cline { 3 - 4 }$(1.0+0.5+2.0)$ & BINA Sarisha -4 & 83.33 & 66.67 \\
& BINA Sarisha -5 & 75.03 & 66.67 \\
& Sampad & 58.32 & 50.00 \\
& Shambal & 50.00 & 33.33 \\
\hline \multirow{3}{*}{$(1.0+1.0+2.0)$} & BINA Sarisha -4 & 75.00 & 58.33 \\
& BINA Sarisha -5 & 66.67 & 58.33 \\
& Sampad & 58.33 & 50.00 \\
& Shambal & 41.67 & 33.33 \\
\hline \multirow{3}{*}{$(2.0+0.5+2.0)$} & BINA Sarisha -4 & 100.00 & 91.67 \\
& BINA Sarisha -5 & 100.00 & 75.00 \\
& Sampad & 83.35 & 66.67 \\
& Shambal & 58.33 & 50.00 \\
\hline & BINA Sarisha -4 & 91.66 & 75.00 \\
$(2.0+1.0+2.0)$ & BINA Sarisha -5 & 75.00 & 66.67 \\
& Sampad & 66.67 & 58.33 \\
& Shambal & 50.00 & 41.67 \\
\hline
\end{tabular}




\subsection{Callus induction from cotyledon}

Cotyledon explants started callus induction from six to nine days of incubation. The percentage of callus induction was highest in BINA Sarisha-4 (91.67\%) followed by BINA Sarisha-5 (75.00\%), and Sampad $(66.67 \%)$. Callus induction was lowest in Shambal $(50.00 \%)$ with the combination of phytohormone treatment $\mathrm{MS}+2$ $\mathrm{mgl}^{-1} \mathrm{BAP}+0.5 \mathrm{mgl}^{-1} \mathrm{NAA}+2 \mathrm{mgl}^{-1} \mathrm{AgNO}_{3}$ (Table 1). Similar result was found by Saha et al. (1997) who reported that callus induction was greatest with $2 \mathrm{mgl}^{-1} \mathrm{BAP}+0.2 \mathrm{mgl}^{-1}$ NAA. Callusing was lowest in MS medium supplemented with $1.0 \mathrm{mgl}^{-1}$ BAP, $1.0 \mathrm{mgl}^{-1}$
$\mathrm{NAA}$ and $2 \mathrm{mgl}^{-1} \quad \mathrm{AgNO}_{3}(33.33 \%$ callus induction) (Table 1). This investigation exhibited that both the high and low concentration of BAP and NAA influences callusing performance.

\subsection{Analysis of variance of different parameters of calli}

The results of analysis of variance (mean squares) for color of callus, nature of callus, abundance of callus, weight of callus, effects of explants, genotypes and different concentration and combinations of phytohormones are presented in Table 2.

Table 2. Mean square values for different parameters of calli

\begin{tabular}{|c|c|c|c|c|c|}
\hline \multirow[b]{2}{*}{ Source of variation } & \multirow{2}{*}{$\begin{array}{l}\text { Degrees } \\
\text { of } \\
\text { freedom }\end{array}$} & \multicolumn{4}{|c|}{ Parameters } \\
\hline & & $\begin{array}{c}\text { Colour of } \\
\text { callus }\end{array}$ & $\begin{array}{c}\text { Nature of } \\
\text { callus }\end{array}$ & $\begin{array}{c}\text { Abundance of } \\
\text { callus }\end{array}$ & $\begin{array}{c}\text { Weight of } \\
\text { callus }\end{array}$ \\
\hline Genotype & 3 & $1.141^{* *}$ & $1.514^{* *}$ & $2.091^{* *}$ & $0.207^{*}$ \\
\hline Explant & 1 & $5.486^{* *}$ & $3.528^{* * *}$ & $4.133^{* *}$ & $1.021^{* *}$ \\
\hline Genotypexexplant & 3 & $0.372^{*}$ & $0.467^{*}$ & $0.607^{*}$ & $0.184^{*}$ \\
\hline Hormone & 3 & $0.941^{* *}$ & $0.980^{* *}$ & $1.404^{* *}$ & $0.224^{*}$ \\
\hline Genotypexhormone & 9 & $0.081^{\mathrm{ns}}$ & $0.074^{\mathrm{ns}}$ & $0.143^{\mathrm{ns}}$ & $0.106^{\mathrm{ns}}$ \\
\hline Explant $\times$ hormone & 3 & $0.146^{\mathrm{ns}}$ & $0.172^{\mathrm{ns}}$ & $0.091^{\mathrm{ns}}$ & $0.187^{*}$ \\
\hline $\begin{array}{l}\text { Explant } \times \text { hormonex } \\
\text { genotype }\end{array}$ & 9 & $0.063^{\mathrm{ns}}$ & $0.075^{\mathrm{ns}}$ & $0.076^{\mathrm{ns}}$ & $0.099^{\mathrm{ns}}$ \\
\hline Error & 96 & 0.215 & 0.224 & 0.182 & 0.140 \\
\hline
\end{tabular}

$* * 1 \%$ Level of significance $\quad * 5 \%$ Level of significance $\quad n s=$ Non significant

Table 3. Performance of different concentrations and combinations of phytohormones on different callus characters of Brassica spp.

\begin{tabular}{|c|c|c|c|c|}
\hline \multirow{2}{*}{$\begin{array}{l}\text { Phytohormone } \\
\text { Combinations }\left(\mathrm{mgl}^{-1}\right) \\
\left(\mathrm{BAP}+\mathrm{NAA}+\mathrm{AgNO}_{3}\right)\end{array}$} & \multicolumn{4}{|c|}{ Character of callus } \\
\hline & Colour of callus & $\begin{array}{c}\text { Nature of } \\
\text { callus }\end{array}$ & $\begin{array}{c}\text { Abundance of } \\
\text { callus }\end{array}$ & $\begin{array}{c}\text { Weight of } \\
\text { callus }\end{array}$ \\
\hline $1.0+0.5+2.0$ & $2.563 \mathrm{~b}$ & $2.570 \mathrm{bc}$ & $2.484 \mathrm{bc}$ & $0.239 \mathrm{bc}$ \\
\hline $1.0+1.0+2.0$ & $2.398 \mathrm{~b}$ & $2.430 \mathrm{c}$ & $2.328 \mathrm{c}$ & $0.228 \mathrm{bc}$ \\
\hline $2.0+0.5+2.0$ & $2.813 \mathrm{a}$ & $2.844 \mathrm{a}$ & $2.828 \mathrm{a}$ & $0.342 \mathrm{a}$ \\
\hline $2.0+1.0+2.0$ & $2.633 \mathrm{ab}$ & $2.680 \mathrm{ab}$ & $2.578 \mathrm{~b}$ & $0.273 \mathrm{ab}$ \\
\hline Level of significance & * & * & $*$ & * \\
\hline
\end{tabular}

Note: Mean values having common letters are statistically identical and those having different letters are statistically different. $* 5 \%$ Level of significance 


\subsection{Effects of the phytohormones}

Mean square values of four different combinations of phytohormones were found statistically significant for the characters color of callus, nature of callus, abundance of callus and weight of callus. MS+2 $\mathrm{mgl}^{-1} \mathrm{BAP}+0.5 \mathrm{mgl}^{-1}$ $\mathrm{NAA}+2 \mathrm{mgl}^{-1} \mathrm{AgNO}_{3}$ was found to be the best for maximum characters such as color of callus, nature of callus and abundance of callus which produced greenish to creamy color, plenty to moderate in abundance and compact to friable natured callus (Table 3 ). Callus weight found highest $(0.342 \mathrm{~g})$ in $\mathrm{MS}+2 \mathrm{mgl}^{-1} \mathrm{BAP}+0.5 \mathrm{mgl}^{-1}$ $\mathrm{NAA}+2 \mathrm{mgl}^{-1} \mathrm{AgNO}_{3}$ and lowest $(0.228 \mathrm{~g}$ ) in $\mathrm{MS}+1 \mathrm{mgl}^{-1} \mathrm{BAP}+1 \mathrm{mgl}^{-1} \mathrm{NAA}+2 \mathrm{mgl}^{-1}$ $\mathrm{AgNO}_{3}$.

\subsection{Effects of the genotypes}

Mean square values for the genotypes were found statistically significant for callus inducing characters like color of callus, nature of callus, abundance of callus and weight of callus indicating significant differences among the genotypes for these characters showed in (Table4). The genotypes BINA Sarisha-4 and BINA
Sarisha-5 produced more greenish to creamy color, compact to friable natured callus, which was plenty to moderate in abundance. Sampad and Shambal produced less greenish to creamy color and friable natured callus. The genotype Sampad produced the largest callus in weight (0.400a). The lowest callus in weight $(0.222 \mathrm{bc})$ was produced by the genotype Shambal which was also lowest in abundance. (Table 4).

\subsection{Effects the of explants}

Mean square values for explants were significant for callus inducing characters like it was found that stem segment produced more greenish colored callus which were plenty to moderate in abundance while cotyledon produced less greenish color and friable natured callus (Table $5)$. Weight of callus was found higher for the explants of stem segment $(0.393 \mathrm{~g})$ than that of cotyledon $(0.214 \mathrm{~g})$. So, it may be concluded that between the explants used, stem segment showed the best performance for callus induction as well as subsequent shoot regeneration (Table 9). Similar results were found by Bhalla and Smith (1998).

Table 4. Performance of the Brassica genotypes on different callus characters

\begin{tabular}{lcccc}
\hline \multirow{2}{*}{ Genotypes } & \multicolumn{4}{c}{ Character of callus } \\
\cline { 2 - 5 } & Colour of callus & Nature of callus & Abundance of callus & Weight of callus \\
\hline BINA Sarisha -4 & $2.758 \mathrm{a}$ & $2.852 \mathrm{a}$ & $2.828 \mathrm{a}$ & $0.254 \mathrm{bc}$ \\
BINA Sarisha -5 & $2.711 \mathrm{a}$ & $2.742 \mathrm{ab}$ & $2.672 \mathrm{ab}$ & $0.339 \mathrm{ab}$ \\
Sampad & $2.602 \mathrm{a}$ & $2.578 \mathrm{bc}$ & $2.484 \mathrm{~b}$ & $0.400 \mathrm{a}$ \\
Shambal & $2.336 \mathrm{~b}$ & $2.352 \mathrm{c}$ & $2.234 \mathrm{c}$ & $0.222 \mathrm{bc}$ \\
\hline Level of significance & $*$ & $*$ & $*$ & $*$
\end{tabular}

Note: Mean values having common letters are statistically identical and those having different letters are statistically different. $* * 1 \%$ Level of significance $* 5 \%$ Level of significance

Table 5. Performance of Explants on different callus characters of Brassica spp.

\begin{tabular}{lcccc}
\hline \multirow{2}{*}{ Explants } & \multicolumn{4}{c}{ Character of callus } \\
\cline { 2 - 5 } & Colour of callus & Nature of callus Abundance of callus & Weight of callus \\
\hline Stem segment & $2.809 \mathrm{a}$ & $2.797 \mathrm{a}$ & $2.734 \mathrm{a}$ & $0.393 \mathrm{a}$ \\
Cotyledon & $2.395 \mathrm{~b}$ & $2.465 \mathrm{~b}$ & $2.375 \mathrm{~b}$ & $0.214 \mathrm{~b}$ \\
\hline Level of significance & $* *$ & $* *$ & $* *$ & $*$ \\
\hline
\end{tabular}

Note: Mean values having common letters are statistically identical and those having different letters are statistically different. $* * 1 \%$ Level of significance, $* 5 \%$ Level of significance 


\subsection{Shoot regeneration}

The final goal of in vitro technique is to establish the explant in culture, resulted in the formation of shoots and subsequently the development of roots for the production of free-living plantlets. MS medium supplemented with different concentrations of BAP, NAA and $\mathrm{AgNO}_{3}$ showed wide variations in shoot proliferation for all the genotypes. The highest shoot regeneration was $58.34 \%$ in phytohormone combination in $\mathrm{MS}+2 \mathrm{mgl}^{-1} \mathrm{BAP}+0.5 \mathrm{mgl}^{-1} \mathrm{NAA}+2 \mathrm{mgl}^{-1}$ $\mathrm{AgNO}_{3}$ from the genotype BINA Sarisha-4 followed by the genotype BINA Sarisha-5 (50.00\%), Sampad (41.67\%) and Shambal $(25.00 \%)$ using stem segment and $33.33 \%$, $25.00 \%$ and $16.67 \%$ using cotyledon, respectively with the phytohormone combinations, $\mathrm{MS}+2 \mathrm{mgl}^{-1} \mathrm{BAP}+0.5 \mathrm{mgl}^{-1} \mathrm{NAA}$ $+2 \mathrm{mgl}^{-1} \mathrm{AgNO}_{3}$ (Table 6).

Plant regeneration depended on diverse factors including the explants, genotypes, hormonal supplements and so on. MS medium supplemented with various concentrations of BAP and NAA showed variation in regeneration potentiality. It was observed from the present study that use of BAP and NAA in the medium helped in shoot regeneration. This result agreement with the findings of Kunshinov et al. (1999) Cao et al., (2003), Du et al. (2000), Wang et al. (2000), Patil and Pillewan (2002) and Sayem (2010). They reported that for shoot regeneration BAP and NAA was the most effective stimulator.

Table 6. Interaction effects of phytohormone $\mathrm{x}$ genotype on shoot regeneration from stem and cotyledon explants of Brassica spp.

\begin{tabular}{|c|c|c|c|}
\hline \multirow{2}{*}{$\begin{array}{l}\text { Phytohormone combinations } \\
\left(\mathrm{mgl}^{-1}\right) \\
\left(\mathrm{BAP}+\mathrm{NAA}+\mathrm{AgNO}_{3}\right)\end{array}$} & \multirow{2}{*}{ Genotypes } & \multicolumn{2}{|c|}{$\%$ shoot initiation } \\
\hline & & Stem & Cotyledon \\
\hline \multirow[t]{4}{*}{$(1.0+0.5+2.0)$} & BINA Sarisha-4 & 33.33 & 16.67 \\
\hline & BINA Sarisha -5 & 25.00 & 16.67 \\
\hline & Sampad & 25.00 & 8.33 \\
\hline & Shambal & 16.67 & 8.33 \\
\hline \multirow[t]{4}{*}{$(1.0+1.0+2.0)$} & BINA Sarisha -4 & 25.00 & 8.33 \\
\hline & BINA Sarisha -5 & 25.00 & 16.67 \\
\hline & Sampad & 16.67 & 0.00 \\
\hline & Shambal & 8.33 & 0.00 \\
\hline \multirow[t]{4}{*}{$(2.0+0.5+2.0)$} & BINA Sarisha -4 & 58.34 & 33.33 \\
\hline & BINA Sarisha -5 & 50.00 & 25.00 \\
\hline & Sampad & 41.67 & 16.67 \\
\hline & Shambal & 25.00 & 16.67 \\
\hline \multirow[t]{4}{*}{$(2.0+1.0+2.0)$} & BINA Sarisha -4 & 41.67 & 25.00 \\
\hline & BINA Sarisha -5 & 33.33 & 25.00 \\
\hline & Sampad & 33.33 & 8.33 \\
\hline & Shambal & 25.00 & 8.33 \\
\hline
\end{tabular}




\subsection{Effects of the phytohormones}

Mean square values due to phytohormone combinations for number of shoot initiation, percentage of shoot initiation and days to shoot initiation were significant indicating that the presence of variability among the treatment used for this study (Table 7). It was found that among the phytohormone combinations, MS+2 $\mathrm{mgl}^{-1}$ $\mathrm{BAP}+0.5 \mathrm{mgl}^{-1} \mathrm{NAA}+2 \mathrm{mgl}^{-1} \mathrm{AgNO}_{3}$ treatment showed significantly highest shoot initiation (1.000) followed by MS+2 $\mathrm{mgl}^{-1} \mathrm{BAP}+$ $1 \mathrm{mgl}^{-1} \mathrm{NAA}+2 \mathrm{mgl}^{-1} \mathrm{AgNO}_{3}$ (0.750) and $\mathrm{MS}+$ $1 \mathrm{mgl}^{-1} \mathrm{BAP}+0.5 \mathrm{mgl}^{-1} \mathrm{NAA}+2 \mathrm{mgl}^{-1} \mathrm{AgNO}_{3}$ (0.562) (Table-7). This result is similar to the observation of Du et al. (2000), Tang and Jhou (2001), Patil and Pillewan (2002) and Sayem (2005). Percentage of shoot initiation was also highest in the treatment of MS+2 $\mathrm{mgl}^{-1} \mathrm{BAP}+$ $0.5 \mathrm{mgl}^{-1} \mathrm{NAA}+2 \mathrm{mgl}^{-1} \mathrm{AgNO}_{3}$ (33.30)which followed by $\mathrm{MS}+2 \mathrm{mgl}^{-1} \mathrm{BAP}+1 \mathrm{mgl}^{-1} \mathrm{NAA}+2$ $\mathrm{mgl}^{-1} \mathrm{AgNO}_{3}$ (24.97). Days require for shoot initiation was less (24.520) in MS+2 $\mathrm{mgl}^{-1} \mathrm{BAP}+$ $0.5 \mathrm{mgl}^{-1} \mathrm{NAA}+2 \mathrm{mgl}^{-1} \mathrm{AgNO}_{3}$ followed by $\mathrm{MS}+2 \mathrm{mgl}^{-1} \mathrm{BAP}+1 \mathrm{mgl}^{-1} \mathrm{NAA}+2 \mathrm{mgl}^{-1}$ $\mathrm{AgNO}_{3}(25.021)$ and $\mathrm{MS}+1 \mathrm{mgl}^{-1} \mathrm{BAP}+0.5$ $\mathrm{mgl}^{-1} \mathrm{NAA}+2 \mathrm{mgl}^{-1} \mathrm{AgNO}_{3}$ (25.440). So, it can be concluded that MS medium supplemented with $2 \mathrm{mgl}^{-1} \mathrm{BAP}+0.5 \mathrm{mgl}^{-1} \mathrm{NAA}+2 \mathrm{mgl}^{-1}$ $\mathrm{AgNO}_{3}$ is the best for shoot initiation and plant regeneration.

\subsection{Effects of the genotypes}

Mean square values due to genotypes for number of shoot initiation, percentage of shoot initiation and days to shoot initiation were significant indicating that the presence of sufficient variability among the genotypes for this characters. It was observed that among the genotypes BINA Sarisha-4 showed the highest number of shoot initiation (0.906) followed by BINA Sarisha-5 (0.812). Percentage was also highest in BINA Sarisha-4 followed by BINA Sarisha-5. Days require for shoot initiation was less (21.750 days) in case of BINA Sarisha-4 indicating best performer which followed by BINA Sarisha-5 (Table-8). From the above discussion it can be concluded that among the genotypes BINA Sarisha-4 is the best performer followed by BINA Sarisha-5 (Table 8).

Table 7. Effects of hormone on different characters of shoot regeneration of Brassica spp.

\begin{tabular}{lccc}
\hline \multirow{2}{*}{$\begin{array}{l}\text { Supplements in } \mathrm{mgl}^{-1}(\mathrm{BAP}+ \\
\left.\mathrm{NAA}+\mathrm{AgNO}_{3}\right)\end{array}$} & $\begin{array}{c}\text { No. of shoot } \\
\text { initiation }\end{array}$ & $\begin{array}{c}\text { Percentage of shoot } \\
\text { initiation }\end{array}$ & $\begin{array}{c}\text { Days to shoot } \\
\text { initiation }\end{array}$ \\
\hline $1.0+0.5+2.0$ & $0.562 \mathrm{bc}$ & $18.73 \mathrm{bc}$ & $25.440 \mathrm{ab}$ \\
$1.0+1.0+2.0$ & $0.375 \mathrm{c}$ & $12.49 \mathrm{c}$ & $25.875 \mathrm{a}$ \\
$2.0+0.5+2.0$ & $1.000 \mathrm{a}$ & $33.30 \mathrm{a}$ & $24.520 \mathrm{c}$ \\
$2.0+1.0+2.0$ & $0.750 \mathrm{ab}$ & $24.97 \mathrm{ab}$ & $25.021 \mathrm{ab}$ \\
\hline Level of significance & $* *$ & $*$ & $*$ \\
\hline
\end{tabular}

Table 8. Effects of genotype on different characters of shoot regeneration of Brassica spp.

\begin{tabular}{lccc}
\hline \multirow{2}{*}{ Genotypes } & \multicolumn{3}{c}{ Parameters } \\
\cline { 2 - 4 } & $\begin{array}{c}\text { No. of shoot } \\
\text { initiation }\end{array}$ & $\begin{array}{c}\text { Percentage of shoot } \\
\text { initiation }\end{array}$ & $\begin{array}{c}\text { Days to shoot } \\
\text { initiation }\end{array}$ \\
\hline BINA Sarisha -4 & $0.906 \mathrm{a}$ & $30.18 \mathrm{a}$ & $21.750 \mathrm{c}$ \\
BINA Sarisha -5 & $0.812 \mathrm{ab}$ & $27.06 \mathrm{ab}$ & $25.565 \mathrm{~b}$ \\
Sampad & $0.562 \mathrm{bc}$ & $18.73 \mathrm{~b}$ & $27.055 \mathrm{ab}$ \\
Shambal & $0.406 \mathrm{c}$ & $13.53 \mathrm{c}$ & $27.692 \mathrm{a}$ \\
\hline Level of significance & $* *$ & $* *$ & $*$
\end{tabular}

Note: Mean values having common letters are statistically identical and those having different letters are statistically different. $* * 1 \%$ Level of significance; $* 5 \%$ Level of significance 
Table 9. Effects of explants on different characters of shoot regeneration of Brassica spp.

\begin{tabular}{lccc}
\hline \multirow{2}{*}{ Explants } & \multicolumn{3}{c}{ Parameters } \\
\cline { 2 - 4 } & $\begin{array}{c}\text { No. of shoot } \\
\text { initiation }\end{array}$ & $\begin{array}{c}\text { Percentage of } \\
\text { shoot initiation }\end{array}$ & $\begin{array}{c}\text { Days to } \\
\text { shoot initiation }\end{array}$ \\
\hline Stem & $0.906 \mathrm{a}$ & $30.18 \mathrm{a}$ & $24.989 \mathrm{~b}$ \\
Cotyledon & $0.437 \mathrm{~b}$ & $14.57 \mathrm{~b}$ & $25.344 \mathrm{a}$ \\
\hline Level of significance & $* *$ & $* *$ & $*$ \\
\hline
\end{tabular}

Note: Mean values having common letters are statistically identical and those having different letters are statistically different. $* * 1 \%$ Level of significance $\quad * 5 \%$ Level of significance

Table 10. Interaction effect of phytohormone x genotype on root initiation of Brassica spp.

\begin{tabular}{|c|c|c|c|}
\hline \multirow{2}{*}{ Phytohormone combinations } & \multirow{2}{*}{ Genotypes } & Stem & Cotyledon \\
\hline & & $\%$ root initiation & $\%$ root initiation \\
\hline \multirow{4}{*}{$\begin{array}{l}1 / 2 \mathrm{MS}+1.0 \mathrm{mgl}^{-1} \mathrm{IBA}+0.5 \mathrm{mgl}^{-1} \\
\text { NAA }\end{array}$} & BINA Sarisha-4 & 66.67 & 58.33 \\
\hline & BINA Sarisha-5 & 58.33 & 58.33 \\
\hline & Sampad & 58.33 & 50.00 \\
\hline & Shambal & 50.00 & 41.67 \\
\hline \multirow{4}{*}{$\begin{array}{l}1 / 2 \mathrm{MS}+2.0 \mathrm{mgl}^{-1} \mathrm{IBA}+0.5 \mathrm{mgl}^{-1} \\
\text { NAA }\end{array}$} & BINA Sarisha-4 & 75.00 & 66.67 \\
\hline & BINA Sarisha-5 & 66.67 & 58.33 \\
\hline & Sampad & 66.67 & 58.33 \\
\hline & Shambal & 58.33 & 50.00 \\
\hline \multirow{4}{*}{$\begin{array}{l}1 / 2 \mathrm{MS}+3.0 \mathrm{mgl}^{-1} \mathrm{IBA}+0.5 \mathrm{mgl}^{-1} \\
\text { NAA }\end{array}$} & BINA Sarisha-4 & 58.33 & 50.00 \\
\hline & BINA Sarisha-5 & 50.00 & 50.00 \\
\hline & Sampad & 41.67 & 41.67 \\
\hline & Shambal & 41.67 & 33.33 \\
\hline
\end{tabular}

Table 11. Survival rate of regenerants of four genotypes of Brassica spp. after transferred into soil

\begin{tabular}{clcc}
\hline & \multicolumn{1}{c}{ Genotypes } & $\begin{array}{c}\text { Stem } \\
\text { Survival rate }(\%)\end{array}$ & $\begin{array}{c}\text { Cotyledon } \\
\text { Survival rate }(\%)\end{array}$ \\
\hline \multirow{3}{*}{ In pot } & BINA Sarisha-4 & 77.78 & 64.28 \\
& BINA Sarisha-5 & 66.67 & 54.54 \\
& Sampad & 58.33 & 50.00 \\
& Shambal & 44.44 & 33.33 \\
\hline \multirow{3}{*}{ In soil } & BINA Sarisha-4 & 64.33 & 55.55 \\
& BINA Sarisha-5 & 54.54 & 50.00 \\
& Sampad & 42.85 & 40.00 \\
& Shambal & 25.00 & 0.00 \\
\hline
\end{tabular}

\subsection{Effects of the explants}

Mean square values due to explants were significant for all the characters studied in this experiment indicating the presence of variability among the explants for these characters. From the Table-9 it may be concluded that, among the two explants, stem segment was the best for all the characters considered for shoot regeneration. 


\subsection{Initiation of roots}

The highest root initiation percentage was $75.00 \%$ in $1 / 2 \mathrm{MS}+2.0 \mathrm{mgl}^{-1} \mathrm{IBA}+0.5 \mathrm{mgl}^{-1} \mathrm{NAA}$ from plants regenerated from stem of the genotype BINA Sarisha-4 followed by the genotypes BINA Sarisha-5, Sampad and Shambal. In the same medium using cotyledon highest percentage $(66.67 \%)$ of root was also obtained from BINA Sarisha-4 followed by BINA Sarisha-5, Sampad and Shambal but it was lower than using stem. Using both the explants (Stem and cotyledon) the performance of Shambal was the lowest $(41.67 \%$ and $33.33 \%$, respectively). From the present study it was evident that the medium $1 / 2 \mathrm{MS}+2.0 \mathrm{mgl}^{-1} \mathrm{IBA}+$ $0.5 \mathrm{mgl}^{-1} \mathrm{NAA}$, the stem explant and the genotype BINA Sarisha-4 are best for root initiation (Table 10).

\subsection{Establishment of plantlets}

After sufficient development of root system, the small plantlets were taken out from the culture vessels without damaging roots. The plantlets then transplanted in plastic pots having soil: sand: cow dung $(1: 2: 1)$ in a lath house for proper hardening. After hardening the plantlets were transplanted to the pots from plastic one, the plantlets were subsequently watered with Hoagland's solution. As soon as new leaves started to initiate the plants were watered with ordinary tap water. Gradually the plantlets were adapted to the soil. The survival rate of plantlet from stem and cotyledon in pot as well as in soil was the highest in the genotype BINA Sarisha-4 (77.78\% \& $64.33 \%$ and $64.28 \%$ \& $55.55 \%$, respectively) followed by BINA Sarisha-5 $(66.67 \%$ \& $54.54 \%$ and $54.54 \%$ \& $50.00 \%$, respectively). The survival rate of plantlet from stem and cotyledon in pot was the lowest in the genotypes Shambal (44.44\% and $33.33 \%)$ (Table-11). Using the same explant the survival rate in the field was the lowest in the genotypes Shambal.

\section{Conclusions}

From the above study it can be concluded that stem segment was better than cotyledon in callus formation, shoot regeneration, root initiation and establishment of plantlets in soil. Among the genotypes, BINA Sarisha-4 performed the best in all cases.

\section{References}

Alam, M. J., Ahmed, K. S., Mollah, M. R. A., Tareq, M. Z. and Chowdhury, M. M. I. 2015. Effect of spacing on mustard yield at Shibganj and Sadar upazila of Bogra district. Bangladesh Journal of Environmental Science, 28: 133-136.

Bhalla, P. L. and Smith, N. A. 1998. Comparison of shoot regeneration potential from seedling explants of Australian cauliflower (Brassica oleracea var. botrytis) varieties. Australian Journal of Agricultural Research, 49(8): 1261-1266.

Biswas, S. K. 2008. Salt tolerance potentials in different Brassica lines at seedling stage and in vitro regeneration ability of some selected varieties. M. S. Thesis. Department of Genetics and Plant Breeding, Bangladesh Agricultural University, Mymensingh. pp. 2-3.

Cao, J. and Earte, E. D. 2003. Transgene expression in broccoli (Brassica oleracea var. italica) clones propagated in vitro via leaf explants. Plant Cell Reports, 21 (8)789-796.

Du, H., Zhuang, D. H. and Hunang, W. H. 2000. Stimulation effect of silver nitrate on shoot regeneration in cotyledon tissue culture of Brassica campestris. Journal of Tropical and Subtropical Botany, 8(2): 109-112.

FAO (Food and agricultural Organization) 2007: FAO Production year Book. Rome, Italy, Vol.61.p.64.

Hachey, J. E., Sharma, K. K. and Moloney, M. M. 1991. Efficient shoot regeneration of Brassica campestris using cotyledon explants cultured in vitro. Plant Cell Reports, 9 (100): 549-554. 
Khaleque, M.A. 1985. A Guide Book on Production of Oil crops in Bangladesh. DAE and FAO/UNDP Project BGD/79/034, 'Strengthening the Agricultural Extension Service' Khamarbari, Farmgate, Dhaka, p. 3.

Kunshinov, V., Koivu, K., Kanerva, A. and Pehu, E. 1999. Agrobacterium tumefaciens-mediated transformation of green house grown Brassica rapa ssp. Oleifera. Plant Cell Reports, 18(9): 773777.

Patil, S. and Pillewan, S. 2002. Callus induction and Plant regeneration in mustard (Brassica juncea). Journal of Advanced Plant Sciences, 15 (2):369-372.

Piazza. G. J. and Foslia, T. A. 2001. Rapeseed oil for oleochemical uses. European Journal of Lipid Science and Technology, 103: 450-454.

Ratan, S., Ranwah, B. R. and Ameta, V. L. 2000. In vitro plant regeneration in Indian mustard. Annals of Biology, 16(2): 217222.

Saha, P. K., Roy, A. and Poddar, R. 1997. Regeneration from cultured floral parts from two cultivars of Brassica juncea. (Czern and Coss). Environmental Ecology, 15(1): 1-3.
Sayem, M. A. 2005. In vitro regeneration through anther culture of Brassica spp. M.S. Thesis. Department of Biotechnology, Bangladesh Agricultural University, Mymensingh. pp. 50-52.

Sayem, M. A. 2010. In vitro shoot regeneration through anther culture of Brassica spp. Bangladesh Journal of Agricultural Research, 35(2): 331-341.

Tang, G. X. and Jhou, W. J. 2001. Studies on the enhancement of plant regeneration frequency in Brassica napus in vitro culture. Journal of Zhejiang University (Agriculture \& Life Sciences), 27 (5): 527-530.

Walker, K. C. and Booth, E. J. 2001. Agricultural aspects of rape and other Brassica products. European Journal of Lipid Science and Technology, 103: 441446.

Wang, J. X., Sun, Y., Cui, G. M., Liu, S. X., Wang, G. P., Shang, Y. J. and Wang, H. 2000. Effects of plant growth regulators and genotypes on the differentiation of in vitro cultured hypocotyls of rapeseed (Brassica). Chinese Journal of Oil Crop Sciences, 22 (1): 11-13. 